\title{
sciendo
}

DOI: $10.2478 /$ rjp-2019-0024

Rom J Psychoanal 2019, 12(1):171-192

Rom J Psychoanal

\section{REFLECTIONS ON THE SPLIT IDENTITY OF WOMEN IN TURKEY OVER CENTURY}

\author{
Nilufer Erdem ${ }^{16}$
}

Abstract: This paper proposes to explain the split of female identity in Turkey in terms of veiled/non-veiled, by attributing it to the exclusion of female founding figures during the instauration phase of the Republic. Introducing the psychoanalytic aspect overlooked in relevant sociological studies, it argues that we can refer to "Republican Girls/Daughters" rather than "Republican Women" and tries to disclose the possible dynamics underlying the split character of female identity in Turkey. As a sample case, it refers to experiences narrated by the novelist Halide Edib, who is also a political figure. The purpose is to demonstrate that the confusion of generations results in the denial of the female figures and leads women on a social level to conflicting dynamics similar to mother-daughter relationship dynamics.

Keywords: denial of the mother, Halide Edib Adivar, veiled/non-veiled women.

\footnotetext{
${ }^{16}$ Psike Istanbul; nilufererdem.psy@gmail.com
} 


\section{Introduction}

A special session was held in a previous international psychoanalytic conference, with the participation of colleagues from Turkey and senior colleagues from other countries who have contributed to the formation of Turkish analysts. During the session, the impact of the nearby war and of certain changes in our country on our clinical work and our daily lives was being discussed informally. The discussion soon led to the question of identity and right after that, to the concerns of the female participants regarding their identity. All of us were surprised by the intensity of the feelings that emerged. Some of us tried to express our concerns and observations, however we saw with great despair that we were unable to find the adequate words to convey our feelings and opinions and that we couldn't develop a significant thought on the subject. Our comments did not go beyond description of sorrow and concern. We were surprised by confrontation with an impossibility. The concrete result of the meeting was an insight, inviting reflection on the experience. This paper is a first attempt on my part in reflecting psychoanalytically on an aspect of the female experience in Turkey, which causes anxiety for women but that they are unable to express.

One of the aspects of this difficulty in reflecting is the present divided political conjuncture that deliberately confronts two social identities - Muslim women and secular women. I intend to center my reflections on this specific split of the social identity of women, which has historical antecedents. I would like to focus on the conflict that this split causes in our inner worlds through the social aspect of female identity. 
The attempt to discuss identity referring to a large social category carries the risk of shifting to sociology. On the other hand, starting out from the clinical experience and concentrating on individual cases does not allow for adequate expression of the actual social impact. In an effort to overcome these drawbacks, at least in part, I tried to bring the example of a female writer, Halide Edib Adıvar, novelist, journalist, politician and one of the founding figures of the Republic of Turkey. I will make some inferences based on the autobiography and novels of the writer who was born in 1884 .

\section{History of the dichotomy of "veiled and non-veiled women"}

The status of women in Turkey has been shaped by the phases of "modernization" starting towards the end of the $18^{\text {th }}$ century in the Ottoman Empire, up to the establishment of the Republic. The administrative, judiciary and military reforms of the $18^{\text {th }}$ century accelerated in the Tanzimat reform era (1839-1871) and had repercussions on social life. Zürcher (1993) holds that the Tanzimat "was also in a sense a cultural revolution, albeit a limited one" (p. 69). The period of expansion in modernization to include women started in 1908 with the second constitutional monarchy ( $2^{\text {nd }}$ Meşrutiyet). Göle (1991) attributes, sociologically, the modernization in terms of the status of women to the tension between three main currents, namely, the Islamist, the Occidentalist and the Turkist movements. The Occidentalist movement advocated equal status for women and men, argueing "that women need to be freed of their 'femininity' and brought to the level of 'humanity"' (Göle, 1991, p. 160). The Islamist movement advocated the conservation of Islamic ethics which it considered fundamental, while the 
Turkist movement argued in favor of restituting the status of women in the ancient Turkish tribes (Turanism). With the establishment of the Republic in 1923 the Occidentalists prevailed and in the following period the opinions of the Turkist movement partially blended in the Kemalist approach. Consequently, the conflict has been carried on between the Occidentalist and Islamist movements both in the general civilization project and on the question of women.

In the first years after the establishment of the Republic, the conflict on the female identity continued to exist in the mute contrast between the republican women who were freed of their veils and the veiled women who made their presence felt like ghosts and who had, so to speak, been driven underground. With the revival of political Islam in the 1980's the ghost presence of the veiled woman has returned in another body and been incarnated in the young veiled female university student who fights for her rights (Göle, 1991).

We can observe that, through the transformations which occurred in the contrasting representations of female identity, the roles attributed to each part in terms of constituting an innovative or conservative, transformative or repressive force, shifted constantly. The "progressive" women open to Occidental values of the first years of the Republic could easily find herself in the position of a conservative nationalist women, while the veiled women of the past seen like monsters and represented the opposition to Occidental values could constitute the new camp that demanded democracy and fought for its rights. As these positions are often manipulated politically, no matter which group they belong to, women defending their rights usually found themselves confronted with "the other camp of women", with feelings of mutual contempt, rejection and denial. For both groups, the other often becomes a distorted 
representation, a reservoir of the projected unwanted aspects of themselves.

For women who adopted the republican ideology veiling has represented, from the beginning, not only the deprivation from social rights but also psychologically being deprived of an independent identity. For the republican women, the veiled woman seemed to represent a dark aspect of the womanhood lying in ambush, one that can engulf her. The fear caused by the universe of the veiled woman (who is pictured strictly confined to home, not sent to school, married very young, responsible for bearing many children, enslaved and possibly forced to share her husband with other women) is so deep-rooted in the imagery of the republican ideology that in the 80's, when young girls wearing a headscarf demanded the right to go to classes with their hair covered, the non-veiled women in power did not seize this demand as an opportunity to support veiled girls in their quest of being liberated of that world which they themselves feared, but perceived it as a trap for themselves and formed a rejection front. These women could not trust that the hand they would extend for solidarity would not pull them into "darkness" which is symbolized by the darkness of bourka.

\section{Meanings of The Veil}

The various meanings that the veil carries has been studied from different viewpoints. The veiling of the Muslim woman is grounded on verses of the Quran regarding the subject. However, even the interpretation of the verses has continued to differ over the centuries (Y1lmaz, 2011). The varying political and sociological meanings of the veil in Turkey have been the subject matter for comprehensive research 
(Göle, 1991, 1999, 2000; Y1lmaz, 2011; Y1lmaz 2015). Yet, research on the psychological meanings of the veil are nonexistent in Turkey to the best of my knowledge. Recent testimonies, that we encounter in electronic media, of women who left the veil reveal the importance for women to have their bodies, and especially their hair, exposed to sun and wind. These women stress that when they left the veil, the memories of the time before they went under the veil came back as rich bodily sensations. An academic research on the psychological aspects of the subject (Ünal, 2016) points out that the veil may represent opposing meanings, that it might serve as a tool to separate from the mother by defeating the illusion of sharing the same skin, while it could also create the same illusion as the mother-daughter were under the same veil in a physical sense. One of the aspects of veiling common to the experience of many women seems to be related with very early bodily experiences and archaic phantasies that it provokes. Iranian psychoanalysts Movahedi and Homayounpour (2013) suggest "viewing the chador as a complex and rich object of fantasy that enjoys multiple functions" and they claim that "at the psychic level, the chador may constitute a cathected object of holding, covering, concealment and invisibility" (p. 201). Examining various meanings of the veil with respect to the varying modalities of the mother-daughter relationship in the analytic situation, the authors claim that the veil does not merely cover, but can serve the function of "skinego" as described by Anzieu as a psychic envelope. They argue that this second skin may serve the function of consolidating the ego while controlling the erotic part of the woman's ego. The authors demonstrate that the veil can be the carrier of the fantasy of the shared skin with the mother or serve a defensive function as a concrete substitute for her; in some cases, become a transitional object as defined by Winnicott and 
facilitate enduring the mother's absence; and in others become the carrier of superego representations constituting "a site of the law of the father" (p. 1360).

The complexity of the meanings of the veil for women allows us to suppose that behind the conflicting positions of Turkish women on social level, as described above, would necessarily lie internal psychic conflicts. As Greenacre (1958) stresses, the sense of identity has also a social component. The inner sense is not enough to produce a sense of identity. The self-image stems from an inner awareness but "it is maintained and perhaps vitalized by the continual redefinement which accompanies comparison and contrast with others" (p. 614). In this sense the veil with its rich meanings should have an important impact on the sense of identity, and it should constitute an object which can hold the representations related to both social and psychic experiences.

The veil can adopt varying meanings in different cultures, which would have repercussions in the internal world of women belonging to that culture. Similarly the socially sustained opposition between veiled and non-veiled women in Turkey has its own dynamics. We can suggest that one of the determining factors about the experience of veil in relation to the female identity, in the case of Turkish culture, is closely connected with how women became visible in the Turkish Republic.

\section{Republican Girls/Daughters}

I believe that in terms of the woman identity promoted by the republican ideology it is difficult to talk about the "Republican Woman" but we can refer rather to "Republican Girls/Daughters" who got on the stage leaving their mothers at home. These Republican Daughters had 
some specific attributes. They have been brought to the front by the Founding Father of the nation, they left the veil and they were given the duty to found the new life hand in hand with the father, as if they were his equivalents in the female world. This attitude in a way abolished the difference of generations, denied the mother's existence, and involved mother and daughter in a conflicting position while also placing father and daughter in a dangerous intimacy. Could we suggest that the image of the veiled woman, which seems menacing still today, represent the mother, and her feminine dimension, whose place has been taken by violating a fundamental rule?

Indeed, these girls, who matured with the Republic and made a place for themselves in society have not had the representative capacity which would embrace the whole women community. While the daughters were encouraged to appear on social scene, women were not immediately given the fundamental rights such as the right to vote and to be elected and they were not encouraged to participate in the sociopolitical life for a longtime.

Every one of these "Republican Daughters" has been chosen and trained to become the first female expert in a particular field. Most of them were given their last names by Mustafa Kemal Atatürk. Two of them were Atatürk's foster daughters: the first female war pilot Sabiha Gökçen and the first female history professor, Afet Inan, one of the creators of the official "Turkish history thesis". Similarly, Keriman Halis Ece, the first Turkish woman to be chosen Miss World was a typical example of these Republican Girls/Daughters. She had shown the world the unveiled body of the Turkish woman. Other examples may be cited: the first female archeologist Halet Çambel, the first Turkish diva Semiha Berksoy, the first female attorney Süreyya Ağaoğlu, the first female war 
correspondent Semiha Es, etc. Most of these women were born in the period from 1910 through the 1920's and belonged to the first generation of children of the Republic established in 1923. They stepped into a different world of womanhood quickly and easily. Even though some of them had mothers who adopted the republican ideals and supported the changing status of women, the girls experienced a radical rupture with the female majority of their mothers' generation.

\section{Women Who Left Their Feminine Dimension and Sexuality at Home}

The model woman of the Republican era was the serious teacher in a grey suit. Young women who have carried out leading roles in other fields have paid the price by sacrificing their feminine dimension. The new state order accepted women to be seen in society, but did not allow them to show their femininity. Thus, a consensus was also reached with the conservative Islamist men who objected to women leaving their homes.

Similarly, Durakbaşa (1983) has emphasized the father-daughter relationship between the founding leader and the women of the newly found state. Durakbaşa states that the other face of that "Kemalist female identity" is the "Kemalist male psyche". She believes that, "with its perfectionism" it has undertaken the mission of "bringing up exemplary 'daughters of the new Republic and the new nation'” (p. 124). She suggests that the Kemalist reformists feared women's sexuality more than the men of the traditional patriarchal system and that they perceived the emancipation of the woman by herself as a menace. The Republican Daughters were charged with bearing in mind that, they had reached their positions and status for a mission. Hamide Topçuoğlu, one of the female 
pioneers in the field of legal sociology expressed the mission given to the Republic's pioneering female students and the power of the father who has given them this mission, with the following words:

Atatürk emancipated women by assigning a duty to her. Even though the professional woman faces a semi-enlightened class who have not yet freed themselves from traditional fixations and masses of people who cannot be held responsible for their ignorance; she feels the support of a powerful modern state. (Quoted and translated Durakbaşa, 1983, p. 135)

Göle (1991) also agrees that "in the Republican era fathers and daughters have assumed the duty of conveying the egalitarian utopia” ( $p$. 106). She asserts that:

The 'Kemalist fathers'-'model daughters' couple inserts the gender-egalitarian ideal and women's public visibility into the social imagination. However, women could carry out their socialization journey, undertaken with men's will, ratification, support and consequently under their control, only by suppressing their identities and sexualities. (p. 108)

Feminist writers have also stressed men's effort to control women's appearance in public, and they have mentioned for instance a "state feminism" (Durakbaşa, 2000; Tekeli, 2017; Zihnioğlu, 2003). The effort to maintain the control on women is certainly an incontestable fact, yet it fails to entirely explain the situation of women. Perhaps what is lacking in these statements is the capacity of the social imagination to produce something more than the ideology inserted into it. The social imagination constantly produces fantasies, rumors, legends, mythologies and ideals. The collective unconscious puts into circulation in various disguises, sexual and other fantasies produced by the interaction of innumerable 
individual unconsciouses. Therefore, we should also take into account, on the one hand the fear of incest and feelings of guilt towards the mother of the daughter, who gets on the stage alongside the father, and, on the other hand, the anxiety of the father himself caused by his role of seductor, as well as his effort to reinstate the boundary that has been overstepped by excluding the mother and promoting the daughter. In Republican Turkey, the dynamics that govern the rivalry among women in the social context have been established all along on this conflicting positions of women, and a big part of it was organized around the image of veil (wearing it/not wearing it).

\section{The Pioneers of Women's Rights and the Major Claims}

It is claimed that women in Turkey have not won their rights by fighting for them, and that their rights were handed down to them by Mustafa Kemal. But a few highlights from history would show that this is not true. Starting with the second constitutional monarchy (1908) women have demanded their rights effectively and insistently. They have founded women's associations at times, although few in number, they have succeeded in being heard through the writings and actions of celebrated writers and activists. The demands of women of the period centered on the abolition of polygamy, the right of women to ask for divorce, their appearance in public life, and keeping the veil. Halide Edib, one of the most popular writers of that era, was attacked by conservative men because of her articles on these themes, published in the newspaper Tanin. She often received anonymous letters and death threats. The letters protested against women becoming visible in the public space and declaring opinions, and maintained that it was against 
religious beliefs. Halide wrote in her memoirs how dissident women and ordinary women of her mother's generation sought her, talked to her on these issues, and related their intimate experiences to her (Adivar, 1963, p. 180). When the first parliament was assembled by Mustafa Kemal in 1920, women raised their voices for their right to vote and be elected. Three years later, when the Republic was established and women were still deprived of the right to vote and be elected, they attempted to found a political party even though they could not participate in the elections. But this endeavor was thwarted by Mustafa Kemal (Çalışlar, 2010). These initiatives prove that, although it had not been written in official history, women were fighting persistently for their rights.

Nevertheless, the stance of the first generation of women's rights defenders on veiling is noteworthy. These pioneering women stressed that they had no demand to unveil. Nakiye Hanım, a close friend of Halide Edib, working for educational rights of women did not think it right for women to be confined to their homes, but she added: "But I don't think it's right for them to unveil either. We Oriental women should at least find a nice headscarf particular to us." (Quoted by Çalışlar, 2010 p. 105). Possibly one reason for this rejection was their unwillingness to jeopardize other rights they might win, as a result of a strong reaction against unveiling on the part of conservative groups and of their own families (husband, parents, etc.). Another reason was women's unpreparedness to unveil. Because the veil is a subjective matter comprising a woman's past experiences in their entirety; it is a part of her identity. The veil or headscarf encompasses all representations of complex family relationships; of the ideals of the parents regarding their child; internalized judgements and attitudes on mother-daughter and father-daughter relationships; and relationships between men and 
women; and of a particular experience of womanhood. Women were trying to say that it could not be expected of them to just cast off this important part of their identities.

\section{The Example of Halide Edib Adıvar}

Halide Edib, who became renowned as a writer from 1908 onward, is an exceptional example who provided insight with her life and work on all the above-mentioned subjects regarding women's status and identity. Her novels reveal her changing thoughts on experiences of womanhood in all its phases without disguise. In her novels, as well as her newspaper articles and studies, she describes both the society she experiences as a woman and the new society she envisions. Her words and actions make her one of the female founders of the Republic and, with her contribution to the National Campaign (or the War of Independence), she deserves to share a status similar to the male founders. In other words, Halide Edib imposes herself as one of the potential female figures that might assume the function of that mother, whose equal contribution to the new state was denied.

One of the features that distinguishes Halide Edib among other female writers and activists is the fact that she has come forward not only with her writings but with her voice and body as well. The speech she gave on May 23 $3^{\text {rd }}, 1919$ in one of the rallies in the Sultanahmet Square against the Greek occupation of Izmir was a sensation. This rally where she addressed approximately 200 thousand men and women is considered one of the signal flares organizing the National Campaign. In fact, when the British occupied Istanbul on May 16th, 1920, they issued a death sentence for six people for organizing the resistance, three of whom were 
Mustafa Kemal, Halide Edib and her husband Adnan Adıvar. ${ }^{17}$ Halide later participated actively in all the phases of the National Campaign. Joining the resistance movement led by Mustafa Kemal, she travelled to Anatolia. She worked in communications and, on Mustafa Kemal's request, founded the Anadolu Agency. She also went to the front as sergeant. Yet, after the war was won and the Republic established, when all her male companions were being assigned duties in the parliament, government or other key positions, Halide was expected to return home. When the first elections were held, women had not obtained the right to vote or be elected yet. When the Anadolu Agency, of which Halide was cofounder and the most active member, was incorporated, all the shares were distributed among the male founders and her name was not mentioned. In the years following the establishment of the Republic, Halide (and her husband) went abroad into voluntary exile as a dissident of Mustafa Kemal. She was in exile when women were given the right to vote and be elected in 1934 . She only returned to Turkey after the death of Mustafa Kemal in 1938.

Halide lost her mother at a very young age and was raised by her maternal grandmother and her father, who was committed to her intellectual development. Her father had Jewish origins, from Thessaloniki, but as an orphan he was raised in a Muslim family in traditional style. He was an enlightened man, who was employed in the service of the Sultan. Halide suffered the depressive mood caused by the loss of her mother. She had a fragile character, and many serious somatizations during her childhood and adulthood, but at the same time she enjoyed an exceptional freedom and intellectual riches in her

17 Her husband Adnan Adivar was the minister of health for the first government of the parliament and later served as vice president of the Assembly. He was also the doctor of Mustafa Kemal's mother. 
upbringing. Her childhood was divided between the house of her pious grandmother and that of her liberal father. She did not belong to the elite upper class as most of the educated women of her time, nor was she like the women of non-Muslim minorities of the Empire. She always lived in popular neighborhoods, in modest conditions, and received the formal religious education before she was enrolled in the American school for girls. She was the genuine type of revolutionary woman, and, unlike the "Republican Daughters", she fought for her rights and she had a legacy to pass on to the coming generations, which she formulated in her memoirs (Adivar, 1962, 1963), and novels. I believe that her legacy to women can be briefly summarized with these words: "Give women the legal support and equal rights, but let them find their own pace to apply reforms." She particularly defended that women should prepare themselves to unveil. We can think that Halide Edib felt the need to ensure "the continuity in time of different representations of the self" (Grinberg and Grinberg,1974) for women to develop an integrated identity. In other words, she strongly felt that, psychically, the reforms in woman's status required an individual psychic elaboration process on the part of the women. Also, probably, she knew by intuition that the veil was a carrier of unconscious meanings for women.

The lecture of her memoirs gives the impression that Halide Edib was regarded as an uncanny figure by her male comrades. The likely reason for this, probably, was that she emphasized her womanhood in a particular style. In her novels, she wrote freely about sexual desires, the most private thoughts and predicament of women. Also, her stance on religion and the veil disconcerted those around her. She was a stout Muslim, but eagerly participated in Bible lessons at the American school. 
In life's changing circumstances she sometimes wore a headscarf and sometimes not.

Halide was married at 16 , and a celebrity and a mother of two boys by the time she was 25 . When her first husband, an acclaimed mathematician and an intellectual who she loved passionately wished to take a second wife, she did not accept and divorced him after approximately ten years of married life. As Durakbaşa (2000) has emphasized, 'In the Ottoman society the 'modern men' assumed the role of pioneers and teachers of modernization, but at the same time they did not want to lose their advantageous status in the Ottoman family system" (p. 232). The apprehension of men when confronted by the feminine aspect of women certainly played a part in this attitude. Halide recounts how she liked to wear bright colored dresses at home, during the first years of her marriage (Çalışlar, 2010). She was trying to be born as a desirable woman in that first marriage. But her husband scorned and even condemned her interest in dressing up and felt it was not compatible with the attitude of an intellectual woman. He tried to dissuade her from this whim with insinuations. Her husband's attitude was no different from her male writer colleagues' and society's attitudes. They did not want to "see" her as a woman.

Halide relates the suppression of her newborn womanhood in her novel Handan (1910). Her novel Yeni Turan (The New Turan, 1912), published two years later describes a utopia where women have the right to vote and where they build society side by side with men. But the ideal Turkish woman she describes in Yeni Turan has given up bright colored feminine clothes; she is always dressed in grey, her face is uncovered, but she wears a white headscarf. Halide states that she was inspired by Quakers for this description. It is interesting that the "Republican 
Girls/Daughters" emerged as very similar to this woman figure save for the headscarf. But this transformation must not be enough, for she was not allowed to be seen in public, holding a political office. Perhaps this had to do with the image of the passionate woman of her first novels lingering still in the minds.

The magnitude of the image of the uncanny woman in the minds of her colleagues seems in fact appalling. While she was living abroad, Halide criticized Mustafa Kemal at one point for turning into a tyrant and she was under heavy attack by pro-Kemal writers. The strong language used then reveals this uncanny feeling and the frightening magnitude of the image of the "rejected other". Newspaper articles explicitly slandered her, calling her a "witch", a "monster", a "freak half-woman, half-man", remarking that she was "in the throes of menopause" (Çalışlar, 2010, p. 360-61). These attributes bring to mind the horror of the feminine dimension that Schaeffer (2011) describes using the term horror feminae and the image of the Gorgon or Medusa. They used her father's Jewish origin as an insult (Çalışlar, 2010, p. 360). "Did you have in mind a chair in parliament? A ministry? Or God forbid, something bigger?" they asked (Çalışlar, 2010, p. 360), as if these aspirations were a crime. The expression "something bigger" surely alluded to the presidency and more than the position itself, emphasized the absurdity of women aspiring to any political office. One of these writers compared Halide's position in relation to Mustafa Kemal, in the political struggle, to his wife's, in an effort to demean Halide and attribute envy and jealousy to her attitude.

“As it can't be helped that every ascent has a descent, you should have resigned yourself to the fact that your star had no right to shine brighter than Latife Hanım's, but you didn't, you couldn't. (...) As a typical woman, she was unable to calculate the havoc wrought by the 
passing years on her face and body. That is why Halide Hanım travels the valleys of dissidence today, appearing now in London and now in America." (Mevlanazade Rıfat's article quoted by Çalışlar, 2010, pp. 364-365).

These attitudes also produced a chasm that damaged the transmission of the female experience among women. They may also have indirectly influenced the opening of the chasm between the female founders of the Republic and the next generation of "Republican Girls/Daughters". Mina Urgan (2006), who was Halide Edib's assistant and later associate professor for years at the university, relates and interprets her professor's wish to manipulate men from offstage based on account of the writer Falih Rifk1:

Halide Edib was determined to impress Mustafa Kemal like she did other men and to dominate him. She wanted Mustafa Kemal to visit her at home and while he was drinking a cup of strong black coffee, ask for her permission: 'Do you think I should announce the establishment of the Republic, Ma'am?' or 'Do you think I should abolish the caliphate, Ma'am?' (Urgan, 2006, pp. 203-204)

These ironic remarks may be based on accurate observations related to Halide's personality. But the manner in which they are expressed evokes the characteristics of the language of conflict between mothers and daughters. What is being related is a fantasized primal scene and the tone is mocking and scornful of the maternal representation. It alludes to the denial of the primal scene qualified thus as impossible. It is significant that the father figure is Mustafa Kemal and that he should be given the name Atatürk, meaning the Ancestor of the Turks. Does this qualification that does not approve of any founding mother with the founding father on the fantasy level, albeit in the shadows, attribute to 
him the property of engendering a lineage on his own? In this case the father could not provide "another 'pair of eyes' that look both at the self and at the self in relationship with mother" (Lemma, 2009), and he could offer nothing but a seducing eye which denies the existence of the mother and leaves the daughter all alone with that persecuting mother who lurked in the shadow.

\section{Conclusion}

As I mentioned at the beginning, this paper is a first effort, on my part, of reflecting on the identity of women in Turkey. It seems to me that it might be significant to trace the mother-daughter conflict in discourses and in the relational modes, as one of the dynamics behind the split female identity in Turkey. Our understanding of the unconscious dynamics of the rupture between two generations of women, which repeated itself in time through next generations, may throw a new light on the questions and answers placed in a social level. Given that our social identity is a part of our self, it is evident that the chasm between women is also a chasm inside each woman. This is another reason why this investigation seems important.

"The phases of revolution and politics come and go, but the whirlpool where the social and human life of the nation spins around is perpetual" remarks Halide Edib (1963, p. 181). I believe that behind the schism of Muslim woman-secular woman today after over a century, women in Turkey are still spinning around in such a whirlpool in search of their identity. In this paper, I proposed to explain that split, with the exclusion of female founding figures during the establishment of the Republic. I have suggested the importance of introducing the psychological dimension overlooked in social research on the subject. I 
argued that we can refer to "Republican Girls/Daughters" rather than "Republican Women". Based on the case of Halide Edib Adıvar, who is also a political figure, I have tried to demonstrate that the confusion of generations results in denial of the mother and leads women into conflicting mother-daughter relationship dynamics. The ideas proposed in there need to be supported by the investigation of other female founding figures.

\section{REFERENCES}

ADIVAR, H. E. (1912) Handan. İstanbul: Özgür Yayınları, pp. 13-208.

ADIVAR, H. E. (1913). Yeni Turan. [The New Turan]. İstanbul: Can Yayınları, 2016, pp. 11-142.

ADIVAR, H. E. (1962) Türkün Ateşle Imtihant. İstanbul: Özgür Yayınları, pp.13-261. [Adıvar, H. E. (1928) The Turkish Ordeal. New York: The Century Co.].

ADIVAR, H. E. (1963) Mor Salkımlı Ev. İstanbul: Can Yayınları, 2017, pp. 173-256. [Adıvar, H. E. (1963). House with Wisteria. Memoirs of Turkey Old and New. New York: Routledge, 2017].

ÇALIŞLAR, İ. (2010). Halide Edib. Biyografisine Siğmayan Kadın. [Halide Edib. The Woman Who Does Not Fit Into Her Biography]. İstanbul: Everest, pp. 63-365.

DURAKBAŞA, A. (1983). The Formation of "Kemalist Female Identity": A Historical-Cultural Perspective. Unpublished BA Thesis in Sociology, Boğaziçi University, İstanbul, pp. 123-138. 
DURAKBAŞA, A. (2000). Halide Edib. Türk Modernleşmesi ve Feminizm. [Halide Edib. Modernization of Turkey and Feminism]. İstanbul: İletişim, $7^{\text {th }}$ Ed. 2017, pp. 13-127 and 169-248.

GREENACRE, P. (1958). Early Physical Determinants in the Development of the Sense of Identity. J. Amer. Psychoanal. Assn., 6:612627.

GRINBERG, L. and GRINBERG, R. (1974). The Problem of Identity and the Psychoanalytical Process. Int. Rev. Psycho-Anal., 1:499-507.

GÖLE, N. (1991). Modern Mahrem. Medeniyet ve Örtünme. İstanbul: Metis, 2016, pp. 43-113. [Göle, N. (1991). The Forbidden Modern. Civilization and Veiling. Michigan: University of Michigan Press].

GÖLE, N. (2000). İslamın Yeni Kamusal Yüzleri. [New Public Faces of Islam]. İstanbul: Metis, 2013, pp. 19-40.

GÖLE, N. (1999). Melez Desenler. İslam ve Modernlik Üzerine. [Hybrid Designs. On Islam and Modernity]. İstanbul: Metis, 2017, pp. 113-158.

LEMMA, A. (2009). Being seen or being watched? A psychoanalytic perspective on body dysmorphia. Int. J. Psycho-Anal., 90(4):753-771.

MOVAHEDI, S. ve HOMAYOUNPOUR, G. (2012). The Couch and the Chador. Int. J. Psycho-Anal., 93(6):1357-1375.

SCHAEFFER, J. (2011). Universal Refusal: A Psychoanalytic Exploration of the Feminine Sphere and its Repudiation. London: Karnac, pp. 117-128. 
TEKELI, Ş. (2017). Feminizmi Düşünmek. [Thinking of Feminism]. İstanbul: İstanbul Bilgi Üniversitesi Yayınları, pp. 181-200.

URGAN, M. (2006). Bir Dinozorun Anılart. [Memoirs of a Dinosaur]. İstanbul: Yapı Kredi Yayınları, pp. 203-205.

ÜNAL, İ. (2016). The Experienceveiling: Conceptualizations of Unveiling in a Ckinical Psychology Context Using Interpretative Phenomenologcal Analysis. Unpublished MA Thesis. Istanbul Bilgi University, Institute of Social Scences, Department of Clinical Psychology.

YILMAZ, B. (2011). Örtünmenin Anlamlart. [Meanings of Veiling] İstanbul: İz Yayıncılık, pp. 43-138.

YILMAZ, Z. (2015). Dişil Dindarllk. İslamcı Kadın Hareketinin Dönüşümü. [Female Piety. The Transformation of the Islamic Women Movement]. İstanbul: İletişim, pp. 107-200.

ZIHNIOĞLU, Y. (2003). Kadinsiz İkzlap. [Revolution Without Women]. İstanbul: Metis, pp. 220-225.

ZÜRCHER, E. J. (1993). Turkey: A Modern History. New York: I.B. Tauris \& Co Ltd., pp. 52-74. 